\title{
Index of Names and Schools
}

Abraham 24, 26-27, 30, 91n16

Academy, Academic school 11-15, 78, 81, 84

Adam 5, 62, 70, 73

Aenesidemus 11

Agrippa 42

Antiochus of Ascalon 12

Arcesilaus 11-14

Arieli, Nahum 8-9, 11

Aristotle 24, 30, 41, 44, 63, 68, 83, 95

Aristotelian, Aristotelianism 9, 13-14, 87, 92

Augustine 14

Ash'ariyya, Ash'arite 21, 23, 28, 90, 93

Baffioni, Carmela 2

Carneades 13-14

Cicero 13-14, 42, 50, 81-82

Clitomachus 13

Crone, Patricia 20

Descartes, René 9, 11

Empedocles 83

Epicurean, Epicureanism 9, 13-14, 87

Falsafah 21, 23, 26-28, 41, 72, 87, 89-92, 95

al-Fārābī, Abū Naṣr 41, 68, 68, 82n121, 94

Galen 15, 67-69, 94

al-Ġazālī, Abū Ḥāmid 3, 9, 11, 28, 32n52, 59n64, 68, 78n111, 80-81, 83, 90-91, 96, 101n3

Harvey, Warren Zev 26n26

Heck, Paul L. 11, 20

Horovitz, Saul 1, 9, 93n21

Ibn Bāǧğah, Abū Bakr 87

Ibn Ezra, Abraham 57

Ibn Ezra, Moses 41-42, 44

Ibn Paqūda, Baḥya 8, 39, 40, 48n40, 51, 53, 65, 69

Ibn Șaddiq, Joseph 69

Ibn Sīnā, Abū 'Alī 27, 48, 84-85, 87

Ibn Tibbon, Judah 8n9

Ibn Tibbon, Samuel 8n9
Kalām 27, 28, 36, 38, 87, 90, 91

Kant, Immanuel 4

Karaite 61

Kaufmann, David 74n104

Maimonides 2, 4, 8, 22, 41, 69, 91-96, 101n3

Moscato, Judah 21n9

Moses 36, 60, 62, 70-71, 73n101

Muhammad (prophet of Islam) 37-38, 59

al-Muqammaș, Dāwūd 60-61

Mu'tazila, Mu'tazilite 21, 61

Neumark, David 74n104

Neoplatonism, Neoplatonic 12, 21, 87

Noah 5, 70, 73

Philo of Alexandria 20

Philo of Larissa 12

Pines, Shlomo 1, 3

Plato 5, 27, 41, 79, 82-83, 99

Popkin, Richard 19

Ptolemy, Claudius 15, 78-79, 94

Pyrrho, Pyrrhonists, Pyrrhonian School 3, 11-

$13,15,42,56 \mathrm{n} 56,78$

al-Rāzī, Faḩr al-Dīn 92-93, 96

Sa'adia Gaon 5, 8, 22, 39, 40, 45, 60-61, 65, 68-71

Samuel Ben Hofni Gaon 61

Sextus Empiricus 11-14

Socrates 5-6, 82-85, 95, 101

Sophist, sophists 15-16

Stern, Josef 2, 8, 93, 96

Stoic, Stoicism, Stoics 9, 13-14, 42, 49, 83, 87

Strauss, Leo 77n107

Șūfī, Șūfism 24, 30, 32n52, 53n51, 90-91

Taku, Moses 88n7

Tertullian 4

Traditionalism, traditionalist 36-38, 45-46, 58-62, 88-89, 91

Veltri, Giuseppe 2

Wolfson, Harry 45 
